\title{
THE HUNTER-GATHERER COMMUNITIES \\ FROM UPPER BIEBRZA BASIN - ENVIRONMENTAL CONTEXT. CASE STUDY FROM LIPOWO SITE (NE POLAND)
}

DOI: http://dx.doi.org/10.18509/GBP.2018.10

UDC: 911.372.3:316.324.22(438)"634"

\author{
Marcin Frączek ${ }^{1}$ \\ Tomasz Kalicki ${ }^{1}$ \\ Adam Wawrusiewicz ${ }^{2}$ \\ Aleksander F. Sanko ${ }^{3}$ \\ Emanuela Malęga ${ }^{4}$ \\ ${ }^{1}$ Jan Kochanowski University in Kielce, Institute of Geography, Department of \\ Geomorphology, Geoarchaeology and Environmental Management, Kielce, Poland, \\ ${ }^{2}$ Podlachian Museum in Białystok, Poland \\ ${ }^{3}$ Belarusian State University, Faculty of Geography, Department of Engineering Geology and \\ Geophisics, Minsk, Belarus \\ ${ }^{4}$ Jan Kochanowski University in Kielce, Institute of Geography, Student Research Group of \\ Geomorphologists „Złoty Bażant”, Poland
}

\begin{abstract}
Study area is located in NE part of Poland in middle Biebrza Basin. Relief of this region formed during Middle Polish (Saalian) Glaciation - Warta Stage. The Biebrza is underfit river with vast peat-bogs on its valley floor. Geological, geomorphological and archaeological studies were conducted at Lipowo site in 2016 excavation season. A beginning of peat accumulation in the valley floor was radiocarbon dated at $8490 \pm 80 \mathrm{BP}$ (MKL-3275) 7658-7347 cal. BC. At the similar time was cut off the Biebrza riverbed near a sandy elevation. Cone from the silty sands in the bottom of this abandoned channel was radiocarbon dated at $8330 \pm 120 \mathrm{BP}$ (MKL-3277) 7577-7083 cal. BC. Both these occurrences, a rise of ground water level and channel change, could be connected with climatic changes - cool and humid phase at the beginning of Atlantic. Results of studies at Lipowo and other sites in Biebrza valley floor indicates some periods of climatic changes and an increase of morphogenetic processes activity. Climate fluctuations correlate very well with flood phases distinguished in Central European river valleys.
\end{abstract}

Keywords: Biebrza Basin, Niemen culture, hunter-gatherers community, Late Neolithic

\section{INTRODUCTION}

Subneolithic formations, the last hunter-gatherer community in the borderland of Eastern and Western Europe, are among the least recognized issues of Polish Prehistory. Undoubtedly it was caused by faint interest of researchers compared to other Neolithic phenomena. However, the main difficulties arise from the nature of the research object. The communities are far advanced traditionalism expressed in both ways the economic, as well as material and spiritual culture [1]. Their way of life, inextricably linked and driven by environmental considerations. Among other things, determined the cyclical nature of the selection and location of encampments. They preferred a small, dry hills situated directly within the valley [2]. Overdoing it with a particular level of complexity 
recently documented sources. Surging surface artifacts obviously were exposed to a number of post depositing factors. This result is their mechanical mixing, and in therefore limited usefulness for the reconstruction of the Prehistoric reality [1]. The only chance to advancement of research is searching for possible stratigraphic homogeneous systems. The recognition of lower-lying edge positions, today covered with peat, creates the best chance to unravel this situation. There is a possibility that surging artifacts are covered, and sometimes separated by successive levels of sediments of various ages and genesis. Ideal conditions for studies of these communities gives the upper Biebrza Basin located in the NE part of Poland. Lipowo is one of three archaeological sites in the Biebrza Basin (Fig. 1) studied in cooperation between Department of Geomorphology, Geoarchaeology and Environmental Management of Institute of Geography, Jan Kochanowski University in Kielce and Podlachian Museum in Białystok. At Lipowo site (red box on Fig. 1) geological, geomorphological, palaeogeographical and archaeological studies were conducted in 2016 excavation season.

\section{GEOLOGICAL AND GEOMORFOLOGICAL BACKGROUND}

Relief of this region formed during Middle Polish (Saalian) Glaciation - Warta Stage. However during the next ice-sheet advance until the Pomeranian phase of last glaciation [3] 15,5-15,0 ka BP, [4] $16.2 \mathrm{ka}$ BP outflow from Naroch-Wilia and Skidel dam lakes and river waters of the upper Neman river followed Łosośna river valley, its tributary Tatarka river breakthrough Pripilin-Nurki gap section to Biebrza and Narew river valleys [3], [5], [6]. Therefore the Biebrza is underfit river with vast peat-bogs on its valley floor. The Pleistocene relief of the valley was transformed in small degree during the Late Glacial and Holocene. In this period controling factors of the evolution were climate and vegetation changes [7].

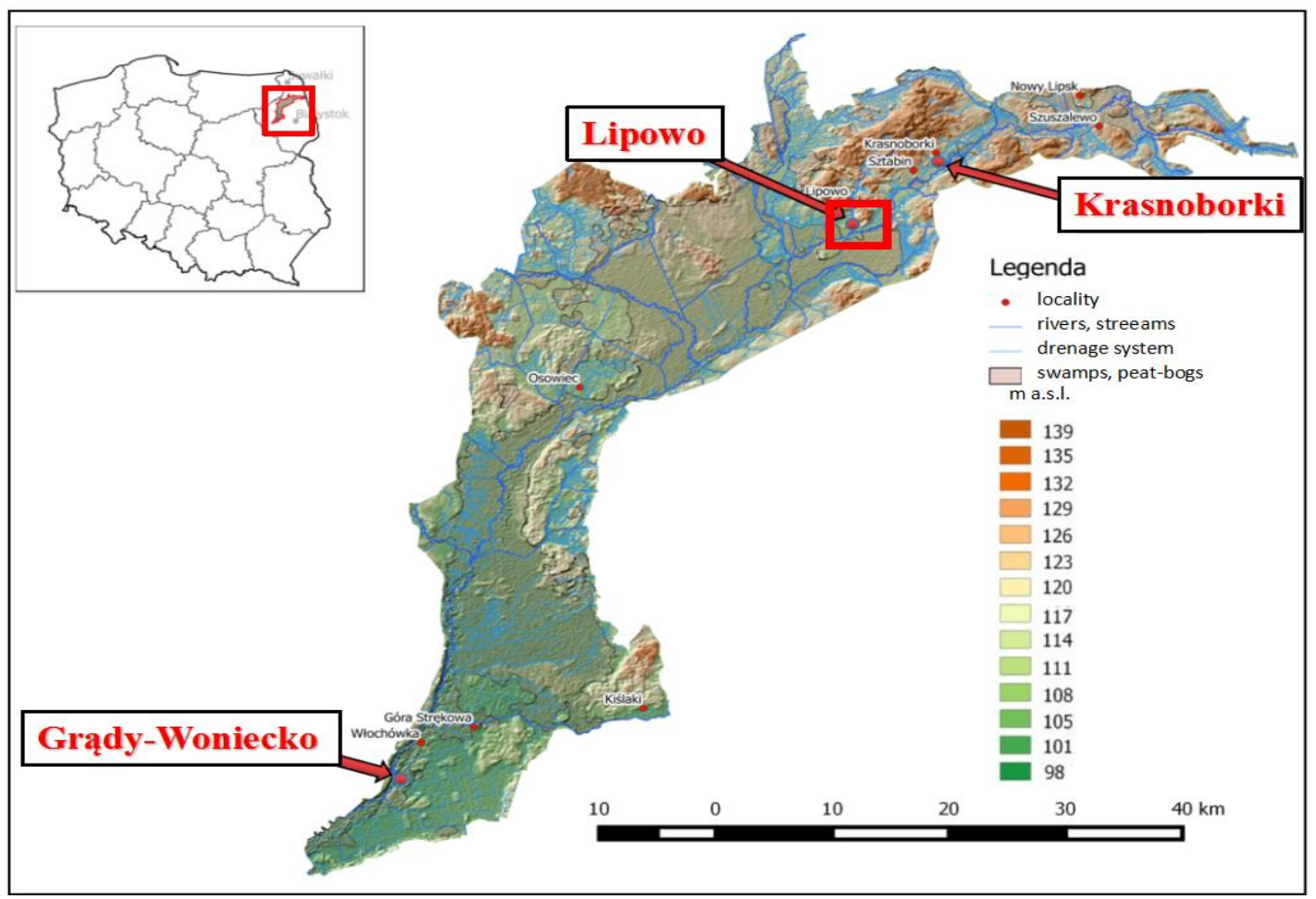

Figure 1. Location of study area in context of other sites in Biebrza Basin [8] 


\section{RESULTS}

Based on off-site studies it was possible to create geological cross-section (Fig. 2). Within of the site and its surroundings can be distinguished three geological segments of different age. The first is an elevation built of dune sands. The second, located at the foot of the elevation, is a part of sandy alluvial plain of braided river. A beginning of peat

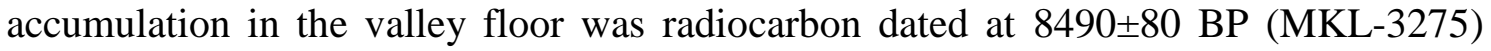
7658-7347 cal. BC. At the similar time was cut off Biebrza riverbed near a sandy elevation. Cone from the silty sands in the bottom of this abandoned channel was radiocarbon dated at $8330 \pm 120 \mathrm{BP}$ (MKL-3277) 7577-7083 cal. BC. This is the third segment (oxbow lake), probably a palaeomeander, as indicated by its parameters (depth and width) (Fig. 2). Both these occurrences, a rise of ground water level and channel change, could be connected with climatic changes - cool and humid phase at the beginning of Atlantic period. This event is globally known as $8.2 \mathrm{ka}$ event [9], [10] and have been indicated also in Central European valleys as a phase of an increase fluvial activity [6]. Detailed sedimentological, geochemical and malacological analysis were made for the core from L5 borehole. For those sediments can be distinguished three members: a channel deposits (I), a lacustrine deposits (II) and marsh/peats sediments (III). At the final stage of the river's functioning, fine sands were accumulated (member I) (Fig. 2). The cut-off Biebrza riverbed (the creation of the oxbow lake) took place about $8330 \pm 120 \mathrm{BP}$ (MKL-3277) cal. 7577-7083 BC, because that was dated a small piece of wood lying in the bottom of the member IIa (on the border between lacustrine and sandy channel deposits) (Fig. 2). After cut off the oxbow lake, the lake phase (II) began, which can be divided into two stages. In the first (member IIa - a thickness about $60 \mathrm{~cm}$ ), when the oxbow lake was still connected with the Biebrza riverbed, fine and silty fine sands were accumulated (Fig. 2). In the second (IIb), autogenic, sedimented organic members carbonate gyttja (content: $10-20 \%$ organic and up to $20 \%$ of $\mathrm{CaCO}_{3}$ ) going up into carbonate gyttja silts (content: $40-50 \%$ organic and up to $15 \%$ of $\mathrm{CaCO}_{3}$ ) (Fig. 2). In carbonate sediments (member IIb) confirmed presence of malacofauna. Gyttja with water malacofauna was accumulated in oxbow lake during the Early Atlantic. Malacological analysis confirm the sedimentological interpretation. In tanatocenosis dominates thermophilic lake mollusc with small amount of river species (Fig. 2). Lake had disappeared about 6170 $\pm 80 \mathrm{BP}$ (MKL-3276) 5313-4911 cal. BC, when started growth of peats (member III) and developed peat bog here [7], [11]. The content of organic matter in the whole member III is approx. 90\% (Fig. 2).

During the archaeological research, three trench excavations were carried out in one 2016 season. Two of them (trenches 1 and 2), with a total area of $20 \mathrm{~m}^{2}$, were made at the southern slope of the elevation and the third (area of $4 \mathrm{~m}^{2}$ ) at the top of the elevation, the purpose of which was to determine the qualitative and quantitative characteristics of the archaeological sources at Lipowo site. Within the archaeological trench 1 - profile E, 15 layers differing in texture, structure, genesis and age were distinguished (Fig. 3). Under organic sediments (layers 1,2,3) two levels of colluvial deposits were found; younger (layers 16, 5) and older (layers 4, 7) built with silty fine sands. In the older colluvial deposits single flint artefacts and animal bones were found (Fig. 3B). In the case of two bone samples, these were bones of the elk's tarsus (one animal), and the next was the tibia bone (most likely a deer) [8]. 


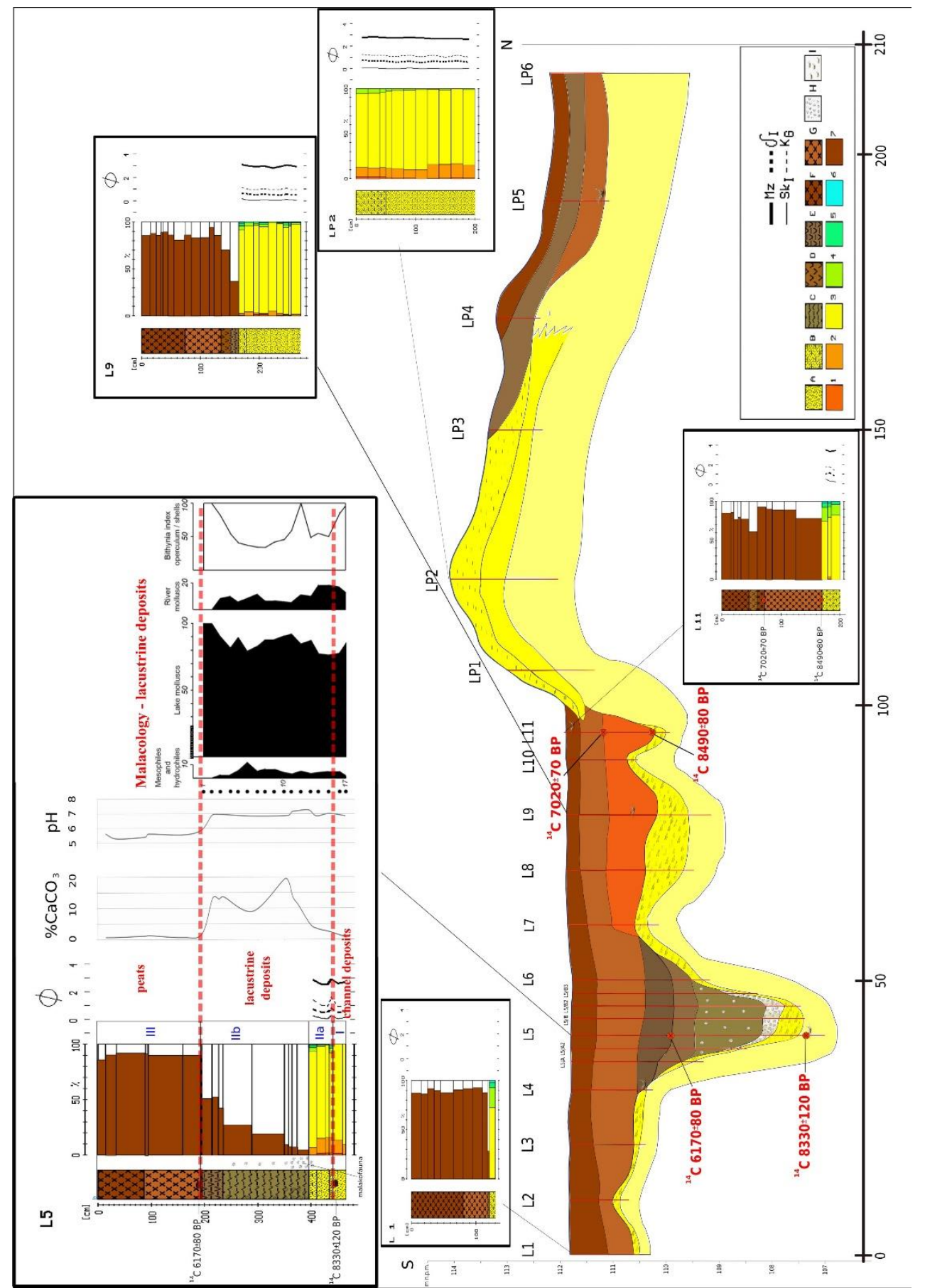

ஜீ

要

品

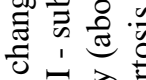

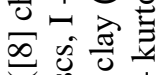

过

릉

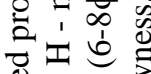

守昰

$\frac{0}{0}$

亮吉

过

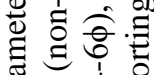

矛过递

范

.0ं

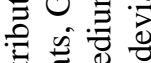

氙

क L'

ज部焉

范范 1

禀空

政守

헝ㅎㅇ

o

कै $\frac{0}{0}$ व

旅芯

का एँ

交方留

응

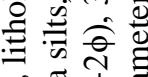

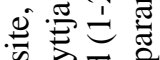

o

定空

战寻

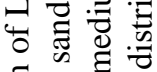

으

氖昰记

它主

की

氖

चี

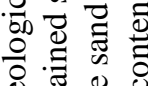

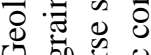

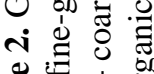

ơ 1100

.

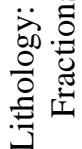


The most distinguishable in terms of morphological characteristics were: upper tooth (belonging to a very old elk) and closer finger member (belonging to the horse), representing an overgrown animal who at the time of death has reached the age of at least isubadultus/adultus [8]. In addition to mammals, in one sample there were very small fish remains, including teeth (pike or catfish?). The older colluvial deposits are partly in superposition to the non-decomposed peats, which hatch at the $2^{\text {nd }} \mathrm{m}$ of excavation, and its thickness increases towards the south (Fig. 3A). In trench 1 only 4 flint artefacts and single bones were found. Fragments of pottery were not found [8].

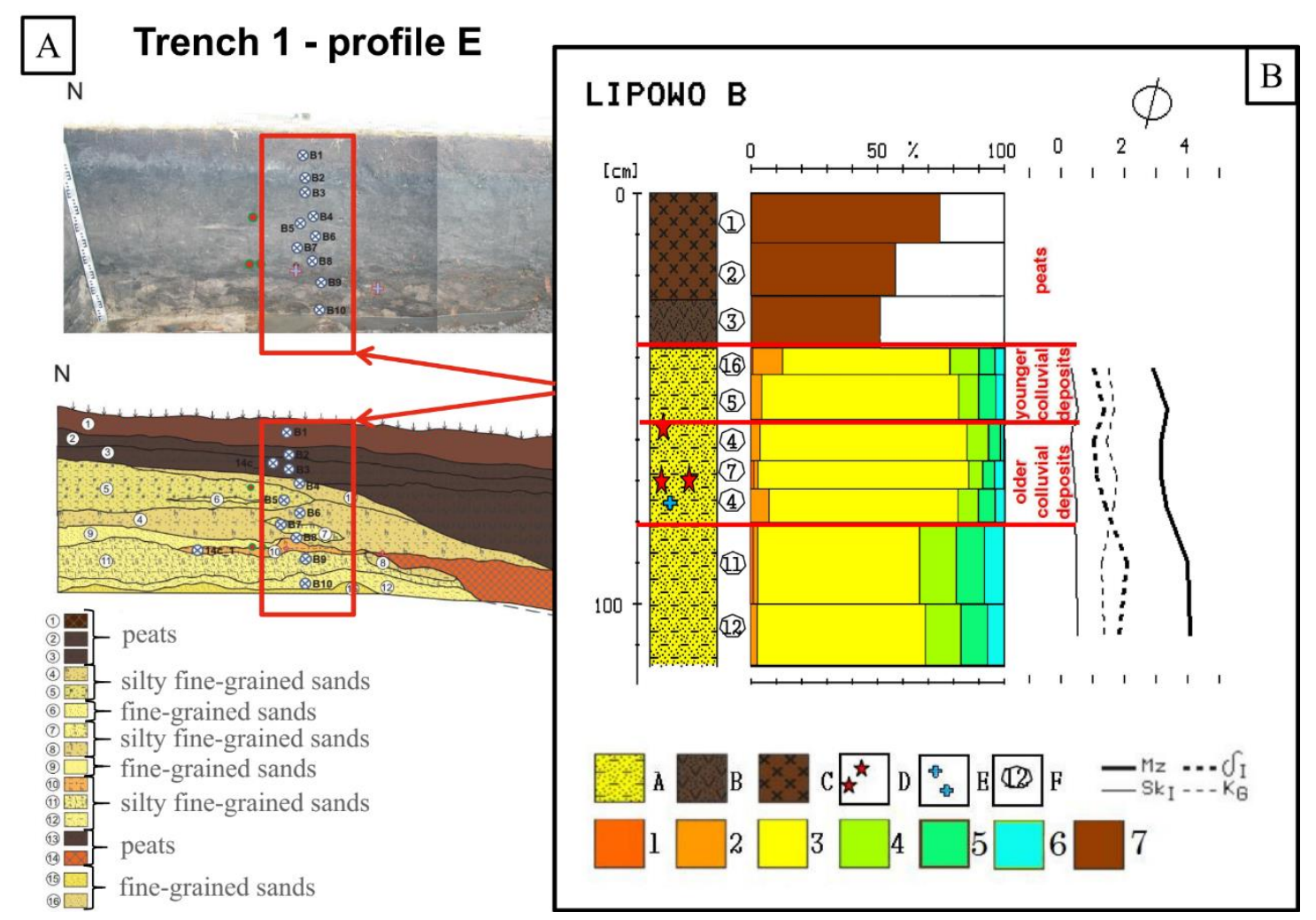

Figure 3. A) Layout of the eastern wall - trench 1, B) Lithology, grain size and Folk-Ward's distribution parameters of Lipowo B profile ([8] changed)

Lithology: A - silty sands, B - silty peats, C - peats, D - single flint artefacts, E - single bones artefacts, F-

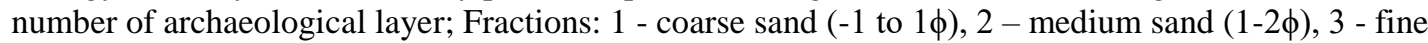

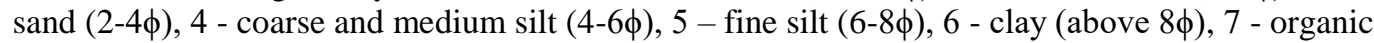
content; Folk-Ward's distribution parameters: Mz - mean diameter, $\delta_{1}$ - standard deviation (sorting), $\mathrm{Sk}_{1}$ skewness, $\mathrm{K}_{\mathrm{G}}$ - kurtosis

The layering system in the profile $\mathrm{N}$ (trench 2) was largely analogous to northern part of trench 1 [8]. Under organic sediments (layers 1,2,3) two levels of colluvial deposits were found; younger (layer 16) and older (layer 5) built with fine-grained silty sands. Under the older colluvial deposits (layer 4) single flint artefacts and animal bones were found (Fig. 4B).

At trench 1 single flint artifacts and animal bones (profile E) occurred. At trench 2 (profile $\mathrm{N}$ ) concentration of flint artifacts with cremated fish bones and animal bones (large mammals, moose/deer/horse) was found. Traseological analysis of flints, indicate that only some of them have macro- and microscopic traces of use [8]. These traces are associated with low-intensity and short-term processing (scraping) of animal skins and cutting of silica plants (herbs). One of the artefact carries the traces of framing, 
macroscopic impact is also visible, which could be interpreted as the blade of a throwing weapon (arrowhead). Single flint artefacts remain in the analogous stratigraphic position at Krasnoborki site (Upper Biebrza Basin). However, at trench 4 on the top of the elevated form were also exposed 3 fragments of pottery on $4 \mathrm{~m}^{2}$. They probably belonged to one vessel, their technological features and the nature of its shape (pointed-bottom) indicate a connection with hunter-gatherer communities of Niemen culture [8]. Presence of the pottery on the top of the elevation may be linked with the settlement function of the Lipowo site.

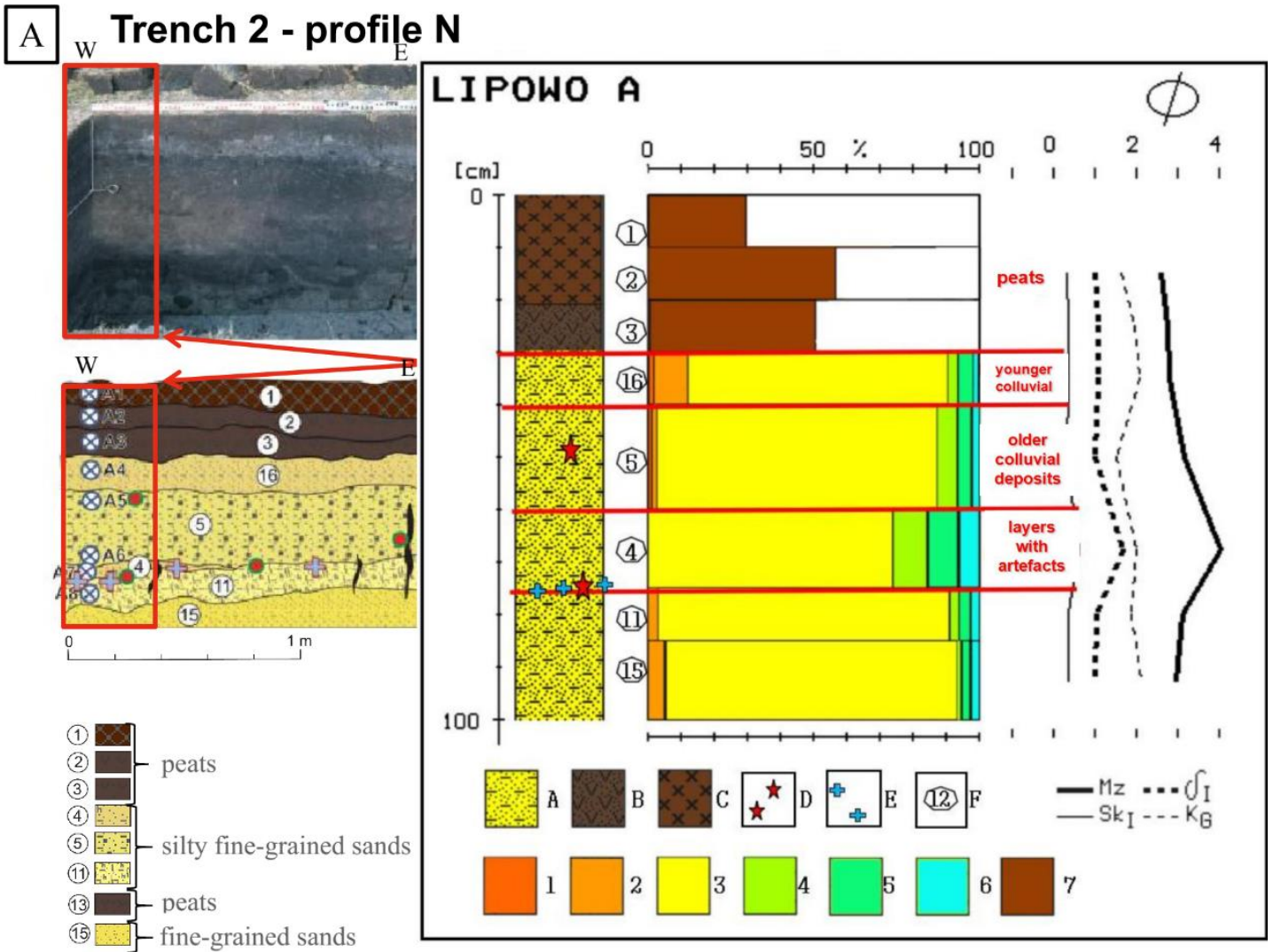

Figure 4. A) Layout of the eastern wall - trench 2, B) Lithology, grain size and Folk-Ward's distribution parameters of Lipowo A profile ([8] changed). Explanations see Fig. 3.

\section{CONCLUSIONS}

Results of studies on Lipowo and other sites in the Biebrza Basin indicates some periods of climatic changes and an increase of morphogenetic processes activity. The oldest phase of cool and humid climate was dated at beginning of Atlantic (growth of peat bogs in valley floor, river channel cut off). The older colluvial deposits at Lipowo were deposited after $7020 \pm 70 \mathrm{BP}$ cal. 6016-5746 BC, which have been covered with peat-bog during the next humid period at the end of the Atlantic (comparison with the Krasnoborki site). Artefacts at Lipowo site were found in the same type of sediments (older colluvial deposits or under them), these layers can be interpreted as the usable level of the encampment from the middle or the younger Stone Age. The technological and morphological characteristics correspond to the general "idea" of the Late-Mezolithic lithic technology of hunter-gatherer communities from the areas of north-eastern Poland from the beginning and the first half of the Atlantic (comp. with [1]). Lipowo site delivers 
new evidence for the co-occurrence of Subneolithic pottery with Mesolithic flint materials. The youngest humid period and beginning of peat accumulation on Subboreal colluvia (probably the same age as younger colluvial deposits at Lipowo site) occurred about 3200-3100 BP (comparison with the Krasnoborki site) [10]. Climate fluctuations correlate very well with phases distinguished in Central European river valleys [6]. Traces of the Subboreal soil erosion and colluvial (delluvial) covers formation occurred on the slope elevation (Krasnoborki) [2], [11].

\section{ACKNOWLEDGEMENTS}

Part of the research was carried out in cooperation with the project: „Preservation of wetland habitats in the upper Biebrza Valley" LIFE11/NAT/PL/422 and funded by Jan Kochanowski University project BS 612480.

\section{REFERENCES}

[1] Wawrusiewicz A., Kalicki T., Przeździecki M., Frączek M., Manasterski D., GrądyWoniecko. Ostatni łowcy-zbieracze znad środkowej Narwi, Białystok, pp.. 320., 2017.

[2] Kalicki T., Wawrusiewicz A., Frączek M., Przepióra P., Kusztal P., Nowak M. Geoarchaeological studies of the Subneolithic site at Krasnoborki (upper Biebrza river valley, NE Poland), Sbornik abstrakt 21. Kvarter (eds. H. Nohalova, V. Káňa, J. Březina), 27.11.2015, Brno, 25, 2015.

[3] Val'chik M. A. Razvitie dolinno-rechnoy seti Belorussii i Pribaltiki v sviazi s degradaciey valdayskogo lednikovogo pokrova [in:] Gidrographicheskaya set' Belorussii i regulirovanie rechnogo stoka.” (ed. L. M. Shirokov). Universitetskoye. Minsk. 3-10, 1992.

[4] Kozarski S. Deglacjacja północno-zachodniej Polski: warunki środowiska i transformacja geosystemu ( 20KA $\rightarrow$ 10KA BP).” Dokumentacja Geograficzna 1, 1995.

[5] Żurek S. Geomorphology of the Biebrza valley [in:] Towards protection and sustainable use of the Biebrza Wetlands: Exchange and integration of research results for the benefit of a PolishDutch Joint Research Plan (eds. H. Okruszko, M. J. Wassen). Utrecht, 15-47, 1994.

[6] Kalicki T. Zapis zmian klimatu oraz działalności człowieka i ich rola w holoceńskiej ewolucji dolin środkowoeuropejskich, Prace Geograficzne IGiPZ PAN 204, pp. 348, 2006.

[7] Kalicki T., Wawrusiewicz A., Frączek M. Upper Biebrza basin - problems of geological, geomorphological and geoarchaeological mappings, Universitetskiye geologicheskiye chteniya „Sovremennyye problemy geologicheskogo kartirovaniya”, 14-15.04.2016, Mińsk, 61-64, 2016.

[8] Frączek M., Warunki przyrodnicze funkcjonowania społeczeństw subneolitycznych w Kotlinie Biebrzy, (typescript of PhD thesis), Biblioteka Uniwersytecka w Kielcach, Uniwersytet Jana Kochanowskiego w Kielcach, Kielce, 2017.

[9] Starkel, L. 8500-8000 yrs BP humid phase - global or regional?, Science Reports of Tohoku University, 7th Series, Geography, 49, 2, 105-133, 2000.

[10] Musiał A. Studium rzeźby glacjalnej północnego Podlasia.” Rozprawy Uniwersytetu Warszawskiego 403, 1992.

[11] Kalicki T., Wawrusiewicz A., Frączek M., Przepióra P., Kusztal P., Nowak M. Late Glacial and early Holocene environmental context of Subneolithic settlement in the Upper Biebrza Basin.” 12 Konference Environmentalni Archeologie „Před neolitem...”, 7-9.02.2016, Praga, Czechy, 29, 2016. 